\title{
BREEDER SPENT FUEL HANDLING PROGRAM MULTIPURPOSE CASK DESIGN BASIS DOCUMENT
}
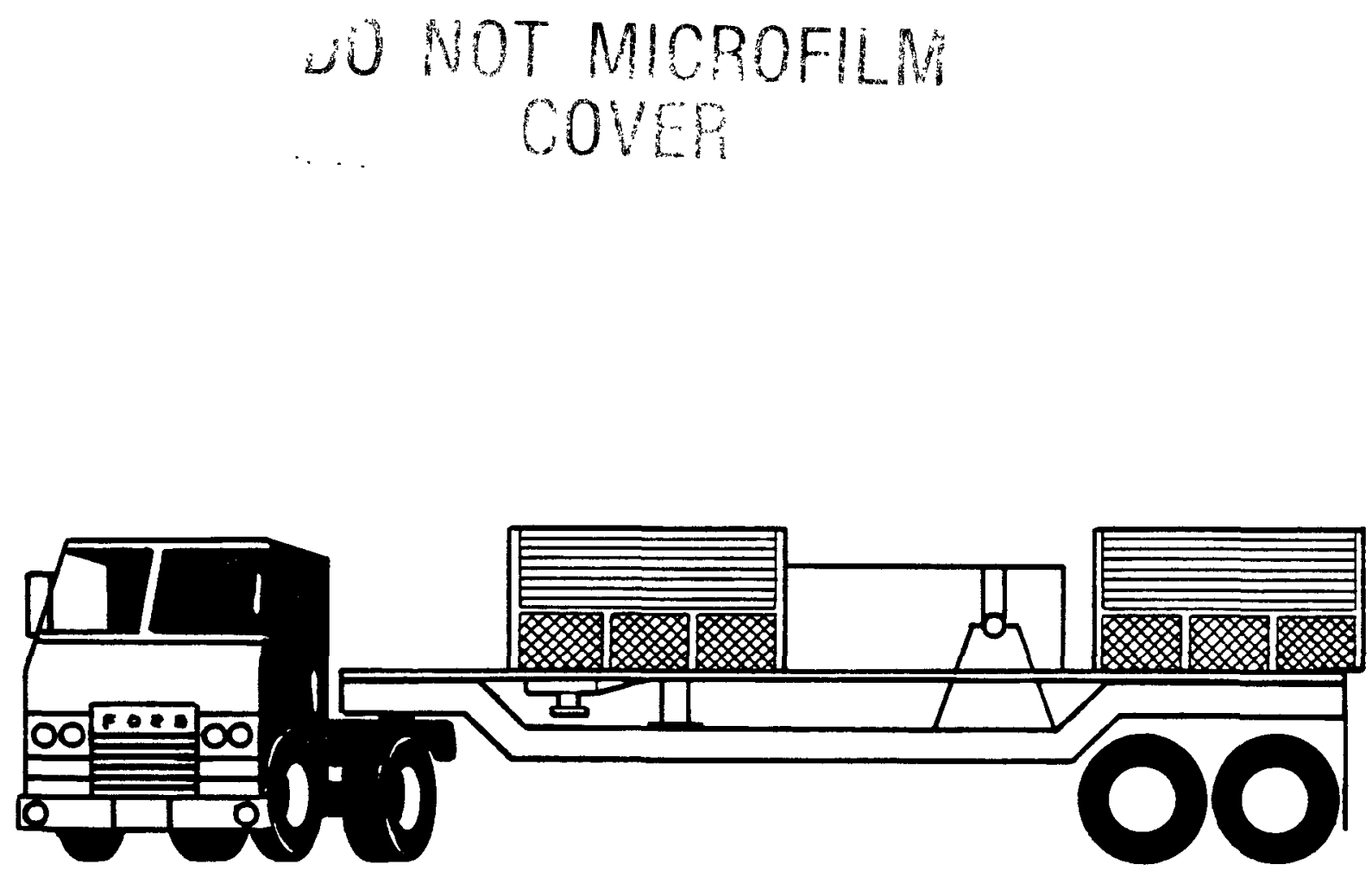

Co-Operative Program with Sandia National Laboratory Transportation Technology Center 


\section{DISCLAIMER}

Portions of this document may be illegible in electronic image products. Images are produced from the best available original document. 


\section{DO NOT MICROFILM COVER}

\section{NOTICE}

This report was prepared as an account of work sponsored by an agency of the United States Government. Neither the United States Government nor any agency thereof, nor any of their employees, nor any of their contractors, subcontractors or their employees, makes any warranty, express or implied, or assumes any legal liability or responsibility for the accuracy, completeness, or any third party's use or the results of such use of any information, apparatus, product, or process disclosed, or represents that its use would not infringe privately owned rights. Reference herein to any specific commercial product, process, or service by trade name, trademark, manufacturer, or otherwise, does not necessarily constitute or imply its endorsement, recommendation, or favoring by the United States Government or any agency thereof or its contractors or subcontractors.

Printed in the United States of America

Available from

National Technical Information Service

U.S. Department of Commerce

5285 Port Royal Road

Springfield, VA 22161

NTIS price codes

Printed copy: A03

Microfiche copy: A01 


\section{BREEDER SPENT FUEL HANDLING PROGRAM MULTIPURPOSE CASK DESIGN BASIS DOCUMENT}

HEDL --7554

DE86 001556

\section{DISCLAIMER}

This report was prepared as an account of work sponsored by an agency of the United States Government. Neither the United States Government nor any agency thereof, nor any of their employees, makes any warranty, express or implied, or assumes any legal liability or responsibility for the accuracy, completeness, or usefulness of any information, apparatus, product, or process disclosed, or represents that its use would not infringe privately owned rights. Reference herein to any specific commercial product, process, or service by trade name, trademark, manufacturer, or otherwise does not necessarily constitute or imply its endorsement, recommendation, or favoring by the United States Government or any agency thereof. The views and opinions of authors expressed herein do not necessarily state or reflect those of the United States Government or any agency thereof.

\section{A.J. Duckett (HEDL) \\ K.B. Sorenson (SNL)}

Date Published: September 1985

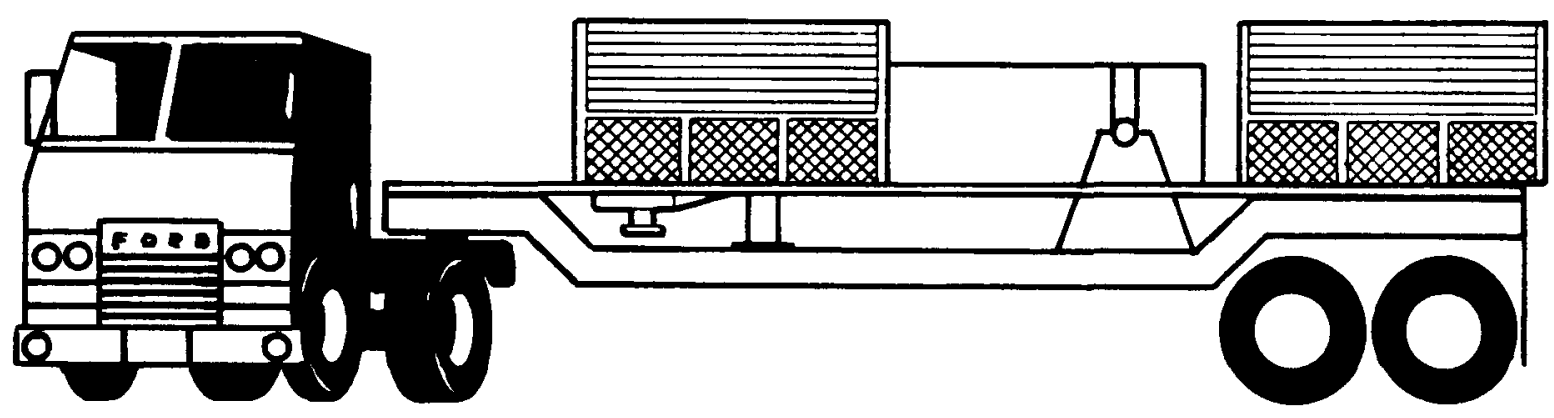

Co-Operative Program with

Sandia National Laboratory Transportation Technology Center

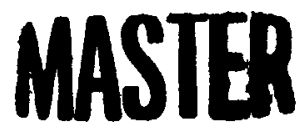

HANFORD ENGINEERING DEVELOPMENT LABORATORY - Operated by Westinghouse Hanford Company, P.O. Box 1970, Richland, WA, a Subsidiary of Westinghouse Electric Corporation. Prepared for the USDOE, Assistant Secretary for Nuclear Energy, Office of Spent Fuel Management and Reprocessing Systems, under Contract No. DE-AC06-76FF02170, B\&R No. AS-15-05. 
BREEDER SPENT FUEL HANDLING PROGRAM MULTIPURPOSE CASK

DESIGN BASIS DOCUMENT

\author{
A. J. Duckett \\ K. B. Sorenson
}

\title{
ABSTRACT
}

The Breeder Spent Fuel Handling (BSFH) Program multipurpose cask Design Basis Document defines the performance requirements essential to the development of a legal weight truck cask to transport FFTF spent fuel from reactor to a reprocessing facility and the resultant High Level Waste ( $H L W$ ) to a repository. 


\section{ACKNOWLEDGMENTS}

The authors wish to acknowledge the contributions of the following individuals in the development of this document.

W. L. Bunch, R. J. Morford, P. A. Ombrellaro and J. 0. Skolrud of Westinghouse Hanford Company. 
Abstract

i i i

Acronyms ix

1.0 INTRODUCTION

2.0 SCOPE $\quad 1$

3.0 APPLICABLE DOCUMENTS

3. 1 GENERAL 1

$\begin{array}{lll}4.0 & \text { DESIGN } & 2\end{array}$

4.1 MATERIAL PROPERTIES 2

4.1.1 General 2

4.1.2 Containment Boundary Components 3

4.1.3 Balance of Packaging Components 3

4.2 CASK STRUCTURAL DESIGN REQUIREMENTS 4

4.2.1 General 4

4.2.2 Evaluation Methods 4

4.2.3 Normal Conditions 5

4.2.3.1 Containment Boundary Components 5

4.2.3.2 Balance of Packaging Components 6

4.2.4 Hypothetical Accident Conditions 6

4.2.4.1 Containment Boundary Components 6

4.2.4.2 Balance of Packaging Components 7

4.3 THERMAL REQUIREMENTS 7

4.3.1 Surface Temperature $\quad 7$

4.3.2 Thermal Expansion 7

4.3.3 Seal Material 7

4.4 CONTAINMENT REQUIREMENTS 8

4.4.1 Normal Transport Conditions 8

4.4.2 Hypothetical Accident Conditions 8 
Page

4.5 SHIELDING REQUIREMENTS 8

4.5.1 Surface Dose Rate 8

4.5.2 Operational Dose Rate 8

5.0 PAYLOAD DEFINITION 9

5.1 PHYSICAL 9

5.2 SOURCE TERM 9

5.3 CRITICALITY 9

$\begin{array}{lll}5.4 & \text { THERMAL } & 10\end{array}$

$\begin{array}{lll}5.5 & 10\end{array}$

$\begin{array}{lll}6.0 & \text { SYSTEM REQUIREMENTS } & 10\end{array}$

$\begin{array}{lll}6.1 & \text { BASKET DEF INITION } & 10\end{array}$

$\begin{array}{ll}6.1 .1 \text { Physical } & 10\end{array}$

6.1.1.1 Interface with Payload 10

6.1.1.2 Interface with Cask 11

6.1.2 Criticality 11

6.1.3 Thermal 11

6.1.4 Mechanical 11

$\begin{array}{lll}6.2 & \text { CASK DEF INITION } & 12\end{array}$

6.2.1 Physical 12

6.2.2 Technical 12

6.2.2.1 Criticality 12

6.2.2.2 Thermal 13

6.2.2.3 Shielding 13

6.2.2.4 Structural 14

$\begin{array}{lll}6.2 .3 \text { Closure } & 14\end{array}$

6.2 .3 .1 Bolts $\quad 15$

6.2.3.2 Seals $\quad 15$

6.2.3.3 Remote Handling 15 
$\underline{\text { Page }}$

6.2.4 Fabrication $\quad 16$

6.2.5 Impact Protection 16

6.2.5.1 Material 16

6.2.5.2 Energy Attenuation 16

6.2.5.3 Attachment 16

$\begin{array}{lll}6.3 & \text { TRANSPORTER DEF INITION } & 17\end{array}$

6.3.1 Cask/Transporter Physical Interface 17

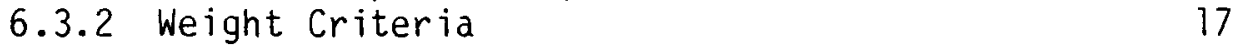

6.3.3 Cask Support Saddles and Tie-Down System 17

6.3.4 Sun Screen 18

$\begin{array}{lll}6.3 .5 & \text { Safety } & 18\end{array}$

$\begin{array}{ll}\text { 6.3.6 Dedicated Systems } & 18\end{array}$

$\begin{array}{lll}7.0 & \text { CASK/FACILITY INTERFACE } & 18\end{array}$

7.1 RECEIVING/SHIPPING 18

$\begin{array}{lll}\text { 8.0 OPERATION AND MAINTENANCE } & 19\end{array}$

8.1 AVAILABILITY 19

$\begin{array}{lll}8.2 & \text { DECONTAMINATION } & 19\end{array}$

$\begin{array}{lll}8.3 & \text { TURN-AROUND TIME } & 19\end{array}$

$\begin{array}{lll}8.4 \text { HANDLING } & 20\end{array}$

8.4.1 Trunnions 20

8.4.2 Remote Handling Capabilities 20

8.5 MAINTENANCE 20

$\begin{array}{lll}9.0 & \text { QUALITY ASSURANCE PLAN }\end{array}$

$\begin{array}{lll}10.0 & \text { REFERENCES } & 21\end{array}$

APPENDIX A REGULATIONS, CODES AND STANDARDS A-1

APPENDIX B PHYSICAL PARAMETERS FOR FFTF FUEL
ASSEMBLIES 
APPENDIX C PHYSICAL PARAMETERS FOR HIGH LEVEL LIQUID WASTE (HLLW) CONTAINER C-

APPENDIX D GAMMA AND NEUTRON SOURCE TERMS FOR FFTF SPENT FUEL

$D-1$

APPENDIX E VITRIFIED WASTE LOG GAMMA RADIATION SOURCE TERMS

$E-1$

APPENDIX F TRUNNION SKETCH

$\mathrm{F}-1$ 


\begin{tabular}{|c|c|c|}
\hline AASHTO & - & $\begin{array}{l}\text { American Association of State Highway and Transportation } \\
\text { Officials }\end{array}$ \\
\hline ANS I & - & American National Standards Institute \\
\hline ASME B\&PV Code & - & $\begin{array}{l}\text { American Society of Mechanical Engineers Boiler and } \\
\text { Pressure Vessel Code }\end{array}$ \\
\hline ASTM & - & American Society of Testing Materials \\
\hline BSFH & - & Breeder Spent Fuel Handling \\
\hline CFR & - & Code of Federal Regulations \\
\hline FFTF & - & Fast Flux Test Facility \\
\hline HEDL & - & Hanford Engineering Development Laboratory \\
\hline HLW & - & High Level Waste \\
\hline LMR & - & Liquid Metal Reactor \\
\hline LSPB & - & Large Scale Prototype Breeder \\
\hline NRC & - & Nuclear Regulatory Commission \\
\hline RH & - & Remote Handling \\
\hline SNL/TTC & - & $\begin{array}{l}\text { Sandia National Laboratory/Transportation Technology } \\
\text { Center }\end{array}$ \\
\hline WHC & & Westinghouse Hanford Company \\
\hline
\end{tabular}


BREEDER SPENT FUEL HANDL ING PROGRAM MULTIPURPOSE CASK

DESIGN BASIS DOCUMENT

\section{$1.0 \quad$ INTRODUCTION}

The Breeder Spent Fuel Handling (BSFH) Program objective is to design, fabricate, license and test a legal weight truck transportation system to service the back-end of the breeder cycle in the shipment of spent fuel from reactor sites to a reprocessing facility, also considering the needs of High Level Waste (HLW) resulting from the reprocessing activities. The cask to be developed should be designed to allow the incorporation of future family members, thus reducing the design and licensing efforts. Future family members may include payloads for the large scale prototype breeder fuel, process facility modification, alternate reactor concepts fuel and high level waste logs from the West Valley Demonstration Project.

\section{$2.0 \quad$ SCOPE}

The activities being performed within the scope of this document are sponsored by the Department of Energy, Division of Fuels and Reprocessing, Germantown, Maryland. This document identifies and defines design constraints and lists the basic performance requirements essential to the development of an engineering design for a legal weight truck packaging (cask) and transportation system to transfer spent fuel from reactors to reprocessing facilities and the resulting High Level Waste to repositories. The scope of this document includes only FFTF spent fuel and HLW vitrified glass logs from reprocessing FFTF spent fuel. Additional cask payload requirements and other pertinent information will be covered by addenda to this document, when the need arises.

\subsection{APPLICABLE DOCUMENTS}

3.1 GENERAL

The applicable documents (Appendix A) form a part of the Design Basis Document to the extent specified in the applicable sections of this document. 
In the event of conflict between documents referenced herein and the requirements of this Design Basis Document, the requirements of this document shall be considered a superseding requirement.

\subsection{DESIGN}

The cask shall be designed to Type B criteria (10 CFR 71) and must be capable of providing the necessary protection to the payload, when subjected to the normal conditions of transport and to the hypothetical accident conditions defined in 10 CFR 71.71 and .73 .

\subsection{MATERIAL PROPERTIES}

\subsubsection{General}

Materials used in the structural fabrication of the cask shall meet the requirements of the ASME B\&PV Code, Sections II and III. Any nonmetallic sealing material will be exempt from this requirement.

Structural material shall be classified as Class 1 , as referenced by NRC Regulatory Guide 7.6 and as defined in ASME B\&PV Code, Section III, Appendix 1. Values for material properties, such as design stress intensities (Sm) and design fatigue curves, are also defined in Section III, Appendix I.

Material properties, such as non-linear stress-strain behavior and strain rate dependent yield and flow data, not available in the ASME code, may be considered in analysis provided the values are technically sound.

In accordance with 10 CFR 71.43, the packaging shall be designed using material that will inhibit chemical, galvanic or other reactions among the packaging components, or between the packaging components and the packaging contents. Minimum wall thickness shall account for any corrosion allowance. 


\subsubsection{Containment Boundary Components}

The cask body, lids and any inner containment liners shall be designed from austenitic stainless steel. Material composition is defined in the ASME B\&PV Code, Section II. Material integrally welded to the containment boundary components, such as neutron shielding covers, impact limiters, impact limiter frames or trunnions, shall be made from austenitic stainless steel.

Gamma-ray shielding shall be steel, lead or depleted uranium. Shielding shall be designed according to the limiting criteria defined in Section 4.5. Weight-to-shielding efficiency should determine the material selection for shielding.

The containment 0 -ring seals shall be compatible with the sealing requirement of ANSI 14.5, Section 5.0 and must be resistant to radiation and other environmental conditions. Any material type must be capable of maintaining a seal during and after hypothetical accident condition events (Section 4.2.4).

\subsubsection{Balance of Packaging Components}

Handling equipment, supports and tie-downs shall be designed to satisfy the equipment requirements. The cask supports and tie-downs shall be designed to withstand the forces specified in Section 6.3. Bolts shall be selected to satisfy the strength, compatibility and brittle fracture requirements of the design.

To protect against brittle fracture, ferritic steel components shall meet the requirement that two out of three Charpy V-Notch tests, per ASTM VE-23, at a temperature of $-20^{\circ} \mathrm{F}$ shall exhibit impact energies greater than $20 \mathrm{ft}-\mathrm{lb}$.

Neutron shielding material shall provide protection against neutron radiation, as specified 10 CFR 71.47 .

The impact limiter material is described in Section 6.2.5. 
4.2 CASK STRUCTURAL DESIGN REQUIREMENTS

4.2.1 General

10 CFR 71 provides the requirements for demonstration of compliance of the package with regulatory loading and environmental conditions. The NRC Regulatory Guide 7.6 describes criteria acceptable to the NRC staff for evaluation of structural design. Load combinations to be evaluated are described in NRC Regulatory Guide 7.8.

Load values to be used for design for both normal conditions and hypothetical accident conditions are defined in 10 CFR 71, Subpart F. The loading crite$\mathrm{ria}$ is not repeated in this document. Structural loads resulting from vibration in transport shall be considered as normal loads in the cask design.

Handling equipment, such as the trunnions, shall be designed to satisfy the requirements of ANSI N14.6 - 1978, "American National Standard for Special Lifting Devices for Shipping Containers Weighting 10,000 Pounds or More for Nuclear Materials." For this product specification, the cask lift shall be considered critical. Therefore, a redundant load path lifting system shall be required.

Cask supports and tie-downs shall be designed to withstand the forces as specified in Section 6.3.3.

\subsubsection{Evaluation Methods}

Paragraph 71.41 of 10 CFR 71 out 1 ines the manner in which compliance with the regulations can be shown:

\subsection{1(a) Demonstration of Compliance}

"The effects on a package of the tests specified in 71.71 (Normal Conditions of Transport) and 71.73 (Hypothetical 
Accident Conditions) must be evaluated by subjecting a sample package or scale model to test, or by other methods of demonstration acceptable to the commission, as appropriate for the particular feature being considered."

For the BSFH Design, "Method of Demonstration" is interpreted as computer analysis or a combination of computer analysis and field testing. In order to demonstrate compliance, any combination of the following analytical/test techniques can be used.

1) Full-scale replication of the package with sufficient instrumentation to resolve the maximum stresses and deformations, and the comparisons with these measured quantities with allowable values as defined in ASME B\&PV Code Section III, Appendix I.

2) Scale model replication, with justification of the scaling laws used, followed by a procedure equivalent to that of (1) above.

3) Replication, either at full-scale or sub-scale, designed to verify and qualify an analytical model. The analytical model is then used to evaluate the package to prescribed normal and hypothetical accident conditions. The results are compared to allowable values as defined in ASME B\&PV Code Section III, Appendix I.

\subsubsection{Normal Conditions}

\subsubsection{Containment Boundary Components}

Ductile Rupture -- The general primary stress intensity, derived from the average value across the thickness of the section and produced by the normal condition mechanical loads, shall be limited to $\mathrm{Sm}$ as defined by the ASME B\&PV Code, Section III. The local primary membrane plus primary bend stress intensities $(P 1+P b)$ shall be limited to $1.5 \mathrm{Sm}$. Secondary and peak stresses are excluded in determining primary membrane and bending stresses. 
Fatigue -- The fatigue requirements of Subparagraph NB-3222.4 of the ASME B\&PV Code, Section III, shall be met where the primary plus secondary stress intensities, excluding peak stresses, do not exceed $3 \mathrm{Sm}$. If the primary plus secondary stress intensity exceeds $3 \mathrm{Sm}$, the criteria of ASME B\&PV Code Section III, Paragraph NB-3228, may be used in lieu of inelastic analytical methods.

Buckling -- Regulatory position C.5 from NRC Regulatory Guide 7.6 states that buckling shall not occur for BSFH containment boundary components subjected to normal transport loads. Compressive stresses shall be limited to two-thirds of the buckling stress. This is consistent with ASME B\&PV Code Section III, Appendix F.

\subsubsection{Balance of Packaging Components}

The balance of packaging components shall withstand the normal conditions of transport with no substantial reduction in the effectiveness of the packaging. To protect against brittle fracture, ferritic steel components must meet the Charpy Values specified in Section 4.1.3.

\subsubsection{Hypothetical Accident Conditions}

\subsubsection{Containment Boundary Components}

Ductile Rupture -- The contaiment boundary shall meet one of the following criteria (see Section 4.2.1):

1) Elastic Analysis - Pm shall be less than or equal to the lesser value of $2.4 \mathrm{Sm}$ and $0.7 \mathrm{Su}$. Also, (Pl + Pb) must be less than or equal to the lesser value of $3.6 \mathrm{Sm}$ and $\mathrm{Su}$ (as defined in ASME B\&PV Code Section III).

2) Inelastic Analysis - Pm and $(P 1+P b)$ must be less than or equal to the greater value of $0.7 \mathrm{Su}$ and $\mathrm{Sy}+1 / 3$ (Su - Sy). 
Buckling -- For BSFH containment boundary components subjected to hypothetical accident loads, compressive stresses shall be limited to two-thirds of the critical buckling stress.

\subsubsection{Balance of Packaging Components}

The balance of the BSFH cask components shall withstand each hypothetical accident condition to the degree required to continue providing protection during the subsequent sequence of hypothetical accident conditions.

\subsection{THERMAL REQUIREMENTS}

\subsubsection{Surface Temperature}

In accordance with the requirements in 10 CFR 71.43 , the accessible external surfaces of the shipping cask shall not exceed $82^{\circ} \mathrm{C}\left(180^{\circ} \mathrm{F}\right)$ assuming still air with an ambient temperature of $38^{\circ} \mathrm{C}\left(100^{\circ} \mathrm{F}\right)$ under normal transport conditions.

\subsubsection{Thermal Expansion}

All components shall be designed to accommodate differential thermal expansion.

\subsubsection{Seal Material}

The selected seal materials shall be compatible with operating temperatures during both normal and hypothetical accident conditions.

The seal materials must maintain their integrity and not exceed their maximum permissible leakage rates (Reference ANSI 14.5 Paragraph 5.3) during normal and hypothetical thermal loading conditions as defined in 10 CFR 71.71 and 71.73 . 


\subsection{CONTAINMENT REQUIREMENTS}

\subsubsection{Normal Transport Conditions}

Under normal transport conditions, as defined in 10 CFR 71.51 , the maximum loss or dispersal of radioactive contents is $10^{-6} A_{2}$ per hour. $A_{2}$ values for single radionuclides are defined in 10 CFR 71.4 and Appendix $A$ of 10 CFR 71 , for a mixture of radionuclides, the $A_{2}$ value will be calculated per Paragraph II of Appendix A. ANSI N14.5 shall be used as guidance for leakage assessment and testing.

\subsubsection{Hypothetical Accident Conditions}

Under hypothetical accident conditions, there should be no escape of Krypton-85 exceeding 10,000 $\mathrm{Ci} /$ week and no escape of other radioactive materials exceeding a total amount of $A_{2}$ in one week. $A_{2}$ shall be defined the same as in Section 4.4.1.

\subsection{SHIELDING REQUIREMENTS}

\subsubsection{Surface Dose Rate}

The design of the shielding for the BSFH cask shall satisfy the requirements of $10 \mathrm{CFR} 71.47$ for a dose rate of $200 \mathrm{mrem} / \mathrm{hr}$ or less for readily accessible surfaces and a rate of $10 \mathrm{mrem} / \mathrm{hr}$ or less at 2 meters $(6.6 \mathrm{ft})$ from any accessible external surface of the vehicle or cask. In addition, the radiation level in any normally occupied position of the transport vehicle shall be $2 \mathrm{mrem} / \mathrm{hr}$ or less.

\subsubsection{Operational Dose Rate}

The shielding shall be designed to minimize radiation exposure to operating personnel. Consideration shall be given to the location of shielding to minimize the dose rate where contact operations may be required. 
The payloads to be addressed include the spent fuel from FFTF and the HLW from reprocessing FFTF spent fuel. Spent fuel definitions are in Appendices $B$ through $E$ of this report.

\section{$5.1 \quad$ PHYSICAL}

The physical dimensions of each payload assembly are given in Appendixes $B$ and $C$. These data provide the general mechanical detail information on the assembly, such as pin diameter, active length of fuel, quantity of fuel etc.

\subsection{SOURCE TERM}

The average photon and neutron source per assembly, decay heat and radiation dose for FFTF spent fuel and HLW log are given in Appendixes $D$ and E, respectively.

\subsection{CRITICALITY}

Federal Regulations (10 CFR 71.55) require every shipment of fissile material to remain subcritical at all times during normal transport, including loading, unloading and under hypothetical accident conditions leading to the most reactive credible configuration. The criticality of a system is discussed in terms of an effective multiplication factor, $K_{\text {effective, which is defined }}$ as the ratio of the neutron production rate to the neutron loss rate of the system. The cask fuel system must remain subcritical, so that the $k_{e f f}$ is less than 1.0 .

The limit for $k_{\text {eff }}$ is 0.95 for normal and hypothetical accident conditions, including corrections for uncertainties. The criticality analysis should be made for the case where the fuel is in the most reactive condition in which it will be transported. This would normally be based on fresh (green) fuel. The criticality of each payload configuration must be determined and the 
design of the inner basket shall contain the appropriate materials, if required, to ensure that the $K_{\text {eff }}$ is less than 0.95 . Neutron source terms are supplied in Appendix E.

$5.4 \quad$ THERMAL

The decay heat for each FFTF spent fuel assembly and HLW log are given in Appendixes $D$ and $E$, respectively. The maximum temperature limit for FFTF spent fuel cladding is $1100^{\circ} \mathrm{F}$. The maximum centerline temperature of the HLW vitrified log shall not exceed $932^{\circ} \mathrm{F}$.

\subsection{LEAKAGE SOURCE TERMS}

The leakage source terms is given in Sections 4.4.1 and 4.4.2.

\subsection{SYSTEM REQUIREMENTS}

\subsection{BASKET DEF INITION}

Baskets may be designed to accommodate one or multiple payload types. All basket designs, however, must be compatible with the cask as defined in this section. Design goals, other than specific criteria used below, shall be ease of payload assembly loading/unloading, ease of basket insertion/removal from the cask, and ease of decontamination.

\subsubsection{Physical}

\subsubsection{Interface with Payload}

The baskets shall be designed to accommodate two payloads: FFTF spent fuel and HLW logs. Physical dimensions of each payload assembly are listed in Appendixes $B$ and $C$ of this document. The assemblies per cask for each payload are: 

FFTF
Goal - seven assemblies/cask, maximum decay heat of $1.2 \mathrm{~kW} / \mathrm{assembly}$
Minimum Acceptable - five assemblies/cask, decay heat of $1.0 \mathrm{~kW} /$ assembly
HLW Logs One assembly/cask, decay heat of $7.6 \mathrm{~kW}$

Each fuel assembly shall be held within the basket to prevent vibration between the basket and the fuel assembly. The fuel assembly shall be longitudinally supported. The basket shall allow for 1 in. of bow in each fuel assembly.

\subsubsection{Interface with Cask}

The BSFH cask inner cavity dimensions shall be established during the design phase. The basket shall be designed to fit into the cask cavity to min gaps between the basket and cask interface. However, operational requirements must be met. Differential thermal expansion between the basket and cask must be taken into consideration in determining clearances.

\subsection{2 $\quad$ Criticality}

The basket must be designed to prevent criticality occurring because of interaction between fuel assemblies. Neutron absorption can be accommodated by inserts or can be incorporated by fabrication of the complete basket from a neutron-absorbing alloy, such as boron/aluminum.

\subsubsection{Thermal}

The basket functions as a mechanism to transfer heat generated from the payload contents to the inner wall of the cask body via radiation and conduction. Materials shall be selected to accommodate this transfer. Differential thermal expansion of dissimilar metals shall be considered in the design.

\section{$6.1 .4 \quad$ Mechanical}

The basket is to be designed as a removable assembly to allow the cask to accommodate multiple payloads. 
For the payload assembly housing within the basket, re-entrant corners are to be radiused and outside corners shall be chamfered for decontamination and payload assembly installation purposes.

The basket can be either monolithic or an assembly of discrete components. Design considerations shall include ease of fabrication, assembly, and installation. Gaps in discrete components should be eliminated so as not to weaken the thermal and structural properties of the basket, to prevent gamma-ray streaming and to aid in decontamination.

\subsection{CASK DEF INITION}

The cask should be designed for remote handling and ease of decontamination. It should have the capability of transport on a legal weight truck. The design should allow commonality for the addition of other family members. The shielding must be weight and cost effective. The cask shall be designed with double containment and have the structural capability to withstand the hypothetical accident scenario. The cask design will accommodate dry loading/un loading.

\subsubsection{Physical}

The cask and associated hardware, including the transporter, shall not weigh more than 80,000 lb. The cask length will be dependent on the payloads to be contained by the cask. The inner shell material must be resistant to caustic corrosion induced by sodium-wetted core assemblies. The inner shell and outer surface should also be easily decontaminated. A design goal for the impact limiters would be an integral system with the cask body.

\subsubsection{Technical}

\subsubsection{Criticality}

The cask and its internals must be designed to assure that fissile materials cannot reach a critical configuration either under normal operation or under 
a hypothetical accident scenario. Nuclear criticality safety will be evaluated for each type of fuel arranged in its most reactive condition.

\subsubsection{Thermal}

Design of the shipping cask must address heat transfer from the payloads to the atmosphere surrounding the cask. The method(s) of heat transfer considered in the cask design phase are dictated by the requirements of maintaining fuel pin cladding temperature and HLW canister centerline temperature within the prescribed limits (Reference Section 5.4 of this report).

The material selected for the cask containment and shielding (gamma-ray and neutron) must be designed to accommodate any differential thermal expansion. The design should allow thermal protection for the seals from internal payload temperatures and from the heat generated by external fires in the hypothetical accident, as defined in 10 CFR 71.73 (see Section 4.3 .1 of this report).

To improve the heat transfer, considerations shall be given to treating the cask and basket surfaces to increase the emissivity. The surface contact and thermal conductance between material interfaces should be reviewed for maximum efficiency. Also, it may be necessary to develope techniques (such as heat pipes) to conduct the heat axially from the fuel region and disperse it along the length of the fuel basket and corresponding portions of the cask.

\subsubsection{Shielding}

The design of the shielding for the multipurpose/multiassembly shipping cask shall satisfy the requirements of 10 CFR 71.47 (see Section 4.5.1). The shielding design should take into consideration shaped shielding to minimize the cask weight. The shaped shielding concept can also be utilized in the inner basket to allow for flexibility in the cask utilization.

The material selected for the gamma-ray shielding is limited to steel, lead and depleted uranium. NRC has become more critical of the use of lead as 
shielding. There is concern that the lead might melt, leaving the cask without adequate shielding. The hypothetical accident fire test, 10 CFR 71.73, requires the cask and shielding to survive for not less than 30 min of a heat flux not less than that of a radiation environment of $800^{\circ} \mathrm{C}\left(1475^{\circ} \mathrm{F}\right)$. Therefore, steel and depleted uranium provide the most logical choices. The depleted uranium provides the most efficient weight-to-diameter ratio. However, fabrication costs for the depleted uranium are greater than steel. The shielding thickness will be controlled by the most restrictive source terms 1 isted in Section 5.2 .

\subsubsection{Structural}

The structural design for the multipurpose/multiassembly shipping cask shall satisfy the requirements of 10 CFR 71, Subpart $E$ and $F$, as outlined in Section 4.2. The cask inner and outer surfaces must be designed for ease of decontamination. All welds should be ground smooth and there should be no cracks or crevices to capture contaminant particles.

The cavity size of 25-3/4 in. ID was selected in the preconceptual design and is compatible with the FFTF spent fuel assemblies and the HLW log from reprocessing LMR spent fuel. Maintaining a common diameter for the various family members should improve the time required for NRC review and licensing. The cavity length will vary with the family member. It is anticipated that the family membership could consist of five casks with the same diameter, but of different lengths.

\subsubsection{Closure}

The BSFH Multipurpose/Multiassembly Cask shall be designed to provide a double containment boundary. The inner shield plug can be made of steel or a combination of steel and depleted uranium. A gas sampling device must be included for the cask cavity. 


\subsubsection{Bolts}

Bolt sizes, quantity and material shall be selected to satisfy the strength, material compatibility and brittle fracture requirements of the design, as stated in Section 4.2.3.2. The bolt sizing for the inner shield plug and the outer cover shall be capable of withstanding the forces imposed by the hypothetical accident scenario (Reference 10 CFR 71.73). The selection of bolting material and thread design should consider the potential for galling. Standardization of bolt sizes should be considered to reduce tool inventory, etc. The bolts shall be designed for remote application (see Section $6.2 \cdot 3 \cdot 3)$.

\subsubsection{Seals}

The containment seals may be metallic, elastomer and/or a combination fabrication. The material must be capable of maintaining a seal during and after all hypothetical accidents, as well as all normal operating temperatures and pressures (Reference ANSI 14.5). The closure system must be designed to retain the seals. However, the seals must be easily replaceable (if required) at facilities not equipped to perform scheduled maintenance. The seal/ closure design must include a system to verify the integrity of the seals.

\subsubsection{Remote Handling}

The cask design shall include features that allow the cask and contents to be loaded/unloaded with remote equipment. The design shall include: (1)

- Details that allow remote alignment of component

- Simple trunnions (see Appendix F)

- Captive spring-loaded bolts for closure plate, shield plug, tiedowns, lifting fixtures, sunshields and impact limitors (if attached)

- Basket

- Remote gas sampling and leak testing system 


\subsubsection{Fabrication}

The cask shall be designed to allow fabrication of the cask by standard manufacturing practices. All structural welds shall be defined as full penetration and all welded gaps and crevices shall be ground smooth on the inner and outer surface of the cask for ease of decontamination. The design requirements must be followed during fabrication to insure a good thermal bond between layers of the cask wall.

\subsubsection{Impact Protection}

The impact protection system limits the forces introduced to the cask and its contents during the hypothetical accident conditions. The impact system shall protect the cask from forces applied to both the exterior and interior surfaces.

\subsubsection{Material}

The material selection for the external and internal impact limitors should provide the necessary protection for the cask and payload.

\subsubsection{Energy Attenuation}

The impact protection system performs its primary function through the energy absorbing mechanism of inelastic deformation. This deformation takes the form of crushing or collapse of the materials to absorb energy. The energy attenuation must be capable of withstanding the hypothetical accident scenario, as defined in 10 CFR 71 subpart F. It is particularly important to protect the cask closure sealing surface from damage and/or deformation.

\subsubsection{Attachment}

The attachment of the impact limitors can be accomplished by bolt-on assemblies or as an integral assembly as discussed in Paragraph 6.2.1. Both 
concepts would require the attachment to withstand the forces induced by the hypothetical accident scenario.

\section{$6.3 \quad$ TRANSPORTER DEF INITION}

\subsubsection{Cask/Transporter Physical Interface}

Physical dimensions of the tractor-trailer rig shall conform to the criteria specified by the American Association of State Highway and Transportation Officials (AASHTO) regulations. The tractor-trailer rig plus contents (cask, sun screen, etc.) shall conform to all AASHTO regulations. Maximum height above the ground for the transporter plus contents shall be $13 \mathrm{ft}$ - 0 in. The cask shall be shipped in the horizontal position.

\subsubsection{Weight Criteria}

The maximum weight of the transporter plus contents shall be 80,000 pounds. Maximum axle weight shall be as specified in the AASHTO regulations. The cask saddles shall be located on the trailer in such a manner as to distribute the cask weight to the trailer axles in proportion to their weight limitations.

\subsubsection{Cask Support Saddles and Tie-Down System}

The cask-to-transporter tiedown system shall be designed such that under normal conditions, the cask can be released from the transporter by a standard remote system and the cask removed from the transporter within a 15-minute time frame, using remote systems and one (1) operator. (1) The support saddles should be designed so that the cask could be off-loaded horizontally or rotated and off-loaded vertically.

The tie-down system and cask supports shall be designed to resist loads based on the forces given as follows: 


\section{Longitudinal 10 times the cask weight plus contents \\ Lateral $\quad 5$ times the cask weight plus contents \\ Vertical 2 times the cask weight plus contents}

The design loads will be applied to the center of gravity of the cask.

\subsubsection{Sun Screen}

Based on cask design sk in temperatures, a sun screen may be required (Reference Section 4.3.1). The sun screen shall be designed to maximize the ease of the cask handling chores around the transporter.

\subsubsection{Safety}

Radiation levels around the transporter are defined in Section 4.5 .1 and in 10 CFR 71.47. Non-fixed (removable) radioactive contamination on the external surfaces of the cask shall not exceed limits prescribed in 49 CFR 173.443. The cask surfaces will be resistant to contamination leaching.

\subsubsection{Dedicated Systems}

The tractor-trailer rig plus associated ancillary components shall be regarded as a dedicated system for exclusive use in radioactive cask transportation.

\subsection{CASK/FACILITY INTERFACE}

\subsection{RECEIVING/SHIPPING}

The cask/facility interface assumptions to be used for the cask design, are as follows:

- $\quad$ Cask loaded weight not to exceed 25 tons 
- The maximum diameter not to exceed 6 feet

- The maximum length not to exceed 18 feet

- Cask and associated lifting fixtures shall be designed for minimum hook height of 30 feet

- Redundant lifting trunnions provided for in-plant handling

- The inner closure plug will be less than $41 / 2$ tons and have a diameter less than 36 inches

- No special maintenance shall be required at loading/unloading station; however, seal replacement shall be possible

- The allowable radiation levels external to the cask are provided in Section 6.3.5

- The accessible external surface temperature of this cask shall not exceed $180^{\circ} \mathrm{F}$ (Section 4.3 .1 )

- The cask must provide a gas sampling port and method of seal verification

8.0 OPERATION AND MAINTENANCE

8.1 AVAILAB ILITY

The cask shall be designed to have an availability of 300 days per year. Cask verification testing, maintenance, etc., shall account for no more than 65 days per year.

\subsection{DECONTAMINATION}

Cask surfaces, exterior and interior, and basket surfaces shall be designed for ease of decontamination. Surfaces shall be smooth without pockets and crevices to facilitate rinsing, drying operations, and to eliminate leaching.

\subsection{TURN-AROUND TIME}

Cask turn-around time shall be defined as the time required to: 
- Off-load the cask from the transporter

- Remove fuel assemblies

- Decontaminate cask and basket

- Prepare cask for future shipments

The design goal for cask turn-around time shall be 24 hours. (1)

\section{$8.4 \quad$ HANDLING}

\subsubsection{Trunnions}

The trunnions shall be bolted to the cask (Reference Appendix F) and designed to lift three times the weight of the cask plus contents per 10 CFR 71.45(a). They shall also meet the requirements in Sections 4.2 .1 and 6.3 .3 of this report.

\subsubsection{Remote Handling (RH) Capabilities}

The cask loading/unloading operation will be designed for remote operation (see Section 6.2.3.3). Remote operation will provide personnel exposure protection during large numbers of cask throughput and allow the facility to automate the operation. (1)

\subsection{MAINTENANCE}

A maintenance plan shall be developed in the design phase of this project. This plan shall include in-service inspection, scheduled maintenance, and corrective maintenance requirements.

\subsection{QUALITY ASSURANCE PLAN}

BSFH design and procurement shall conform to the Quality Assurance requirements specified in NRC Regulatory Guide 7.10, Annex 1, and 10 CFR 71, Subpart $H$. 
A Quality Assurance Plan will be prepared for the project at the earliest possible time during the design phase. The QA plan shall establish authority and responsibility for quality assurance activities within the project.

Quality assurance activities will be written for all phases of program development. These phases include: design, SARP, fabrication, testing, and operation.

The Quality Assurance Plan shall specify procedures for reporting and correcting significant deficiencies, defects, and nonconformances. Requirements for reporting significant deficiencies will be extended to suppliers in procurement documents.

Quality Assurance activities shall be applied with a graded approach. The level of $Q A$ effort shall be consistent with an activities' importance to safety and performance.

\subsection{REFERENCES}

1. HEDL-7376, TTC-0449, Rev. 1, "Conceptual Design Report for a Remotely Operated Cask Handling System." 


\section{A P PENDIX A}

REGULATIONS, CODES AND STANDARDS

$A-1$ 
APPENDIX A

REGULATIONS, CODES AND STANDARDS

\section{A.1 DEPARTMENT OF ENERGY (DOE)}

A.1.1 DOE 1540.2, "Administrative Procedures Hazardous Material Packaging for Transport," draft dated November 15, 1984.

A.1.2 DOE 5480.3, "Safety Requirements for the Packaging and Transportation of Hazardous Material, Hazardous Substances and Hazardous Wastes," dated July 9, 1985.

\section{A.2 NUCLEAR REGULATORY COMMISSION (NRC)}

A.2.1 10 CFR 71, "Packaging and Transportation of Radioactive Material," August $31,1983$.

A.2.2 Regulatory Guide 7.4, "Leakage Tests on Packages for Shipment of Radioactive Materials," June 1975.

A.2.3 Regulatory Guide 7.6, "Design Criteria for the Structural Analys is of Shipping Cask Containment Vessels," March 1978.

A.2.4 Regulatory Guide 7.8, "Load Combinations for Structural Analysis of Shipping Casks," May 1977.

A.2.5 Regulatory Guide 7.9, "Standard Format and Content of Part 71 Applications for Approval of Packaging of Type B, Large Quantity and Fissile Radioactive Material," Revision 1, January 1980.

A.2.6 Regulatory Guide 7.10, "Establishing Quality Assurance Program for Packaging Used in the Transport of Radioactive Materials," January 1983.

A.3 AMERICAN NATIONAL STANDARDS INSTITUTE (ANSI)

A.3.1 ANSI N14.2, "Tie-Downs for Transport of Fissile and Radioactive Material Containers Greater than One Ton Truck Transport," (draft of document under review).

A.3.2 ANSI B30, "Lifting Devices." 
A.3.3 ANSI N14.5, "Leakage Tests on Packages for Shipment of Radioactive Material," 1977.

A.3.4 ANSI N14.6, "Special Lifting Devices for Shipping Containers Weighing 10,000 Pounds or More for Nuclear Materials," (draft of document under review).

A.3.5 ANSI N14.8, "Fabricating, Testing and Inspection of Shielded Shipping Casks for Irradiated Reactor Fuel Elements," (new document to be written).

A.3.6 ANSI N14.10.1, "Administrative Guide for Packaging and Transporting Radioactive Materials."

A.4 AMERICAN SOCIETY OF MECHANICAL ENGINEERS (ASME) BOILER AND PRESSURE VESSEL CODE

A.4.1 Section II, Material Specification

A.4.2 Section III, with Appendices - Nuclear Power Plant Components

A.4.3 Section IX, Welding and Brazing (Repair)

A.4.4 Section XI Rules for In-Service Inspection of Nuclear Power Plant Components

A.5 OTHER

A.5.1 49 CFR 173, Department of Transportation, "Shippers General Requirements for Shipments and Packaging," dated May 1984.

A.5.2 ANSI/ASME NQA-1-1979, "Quality Assurance Program Requirements for Nuclear Power Plants."

A.5.3 International Atomic Energy Agency (IAEA) Safety Series No. 6, "Regulations for the Safe Transport of Radioactive Materiai," 1973 Revised Edition.

A.5.4 American Association of State Highway and Transportation Offices (AASHTO) .

A.5.5 American Society of Testing Material (ASTM) VE-23. 


$$
\text { A P PENDIX B }
$$

PHYSICAL PARAMETERS FOR FFTF FUEL ASSEMBLIES

B-1 
TABLE B. 1

PHYSICAL PARAMETERS

Fuel Pin

Active Fuel Length

$36.0 \mathrm{in.}$

Clad Material

316 SST

Clad Thickness

$0.38 \mathrm{~mm}$

Pin Dimensions

- Diameter

- Length

$5.80 \mathrm{~mm}$

$2.38 \mathrm{~m}$

Driver Fuel Assembly

$\begin{array}{lc}\text { Shape (Diameter) } & 4.72 \mathrm{in.} \text { (hex) } \\ \text { Length } & 144.0 \mathrm{in} . \\ \text { Weight } & 500.0 \mathrm{lb} \\ \text { No. of Pins/Assembly } & 217 \\ \text { Fuel Pin Array Pitch } & 7.3 \mathrm{~mm} \\ \text { Specific Power (MW/MTHM) } & 161 \\ \text { Heavy Metal Weight } & 33.0 \mathrm{~kg} \\ \text { Initial Enrichment } \frac{\mathrm{Pu}}{\mathrm{Pu}+\mathrm{U}} \mathrm{O} & \text { Range } 22.4 \text { to } 30.9 \\ \text { End-of-Burnup Enrichment } \frac{\mathrm{Pu}}{\mathrm{Pu}+\mathrm{U}} \% & \text { Range } 21.4 \text { to } 29.1 \\ \text { Axial Burnup Profile } & \text { See Page B-3 }\end{array}$




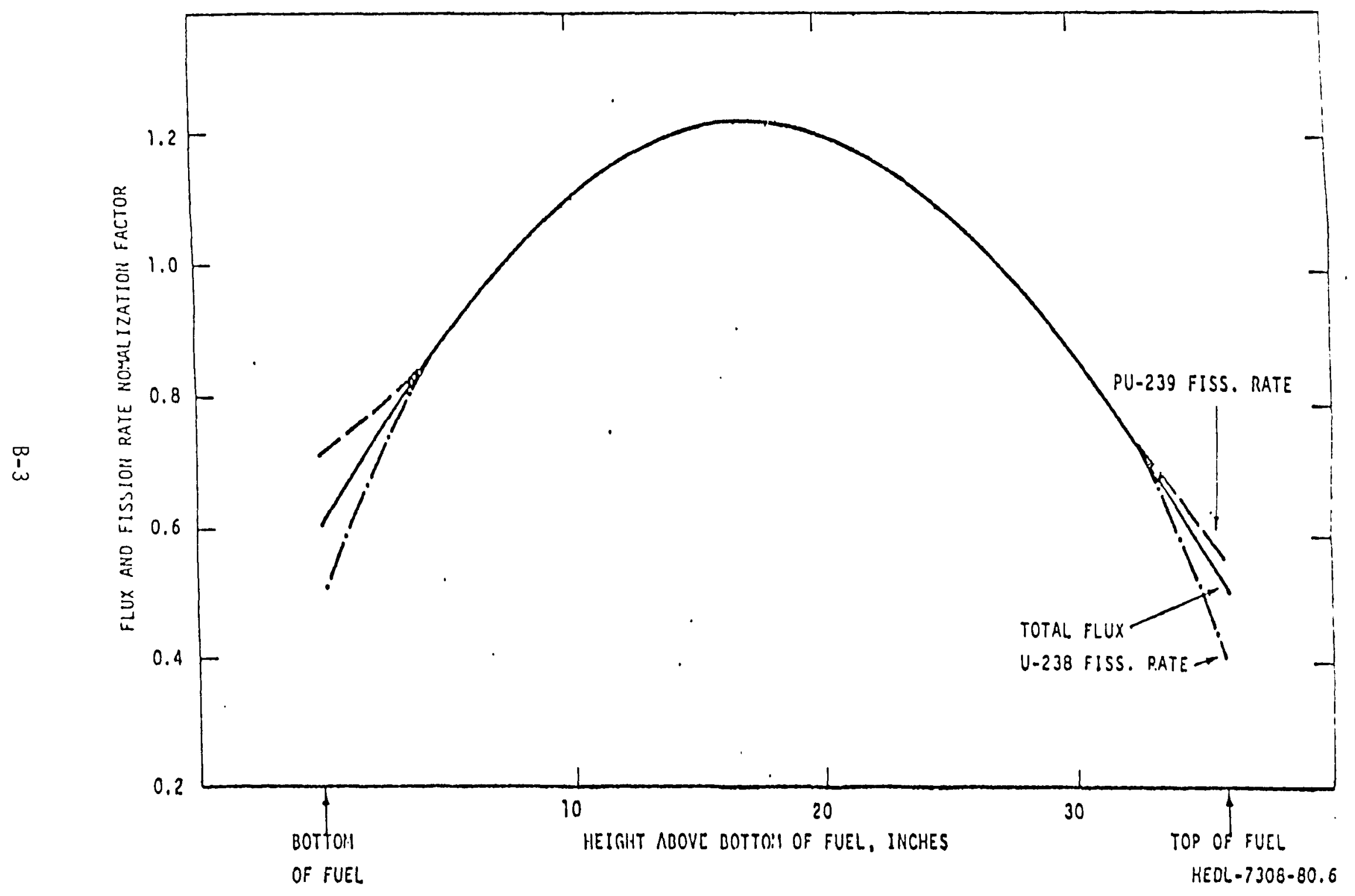

FIGURE B.1. Axial Flux and Fission Rate Distributions, Rods Fully Withdrawn. 
A P P E N D I X C

PHYSICAL PARAMETERS FOR HIGH LEVEL LIQUID WASTE (HLLW) CONTAINER 


\section{TABLE C. 1}

HIGH LEVEL LIQUID WASTE (HLLW) CONTAINER

\section{Parameter}

Canister ID (in.)

Waste 0xide to Vitrify ( $\mathrm{kg} / \mathrm{campaign}$ )

HLLW to Process (L/campaign)

Allowable Heat Density in Glass (W/L)

Caniter Length ( $\mathrm{ft}$ )

Canister Fill Depth ( $\mathrm{ft}$ )

Glass Volume (L/canister)

Total Heat Loading in Canister ( $\mathrm{kW}$ )

Glass Density $(\mathrm{g} / \mathrm{ml})$

Glass Produced (kg/canister)

Number of Canisters/Campaign

Waste Loading in Glass (wt\%)

Glass Production Rate Required $(\mathrm{kg} / \mathrm{hr})$ *

Feed Concentration ( $g$ oxide/ $L$ )

Average Feed Rate Required (L/hr)*
Size

12-in.

12.25

211

1281

41

10

8

185.4

7.6

2.8

519

5.0

8.1

3.6

325

11.2

*For 30-day campaign, matching reprocessing rate. 


$$
\text { A P P N D I X D }
$$

GAMMA AND NEUTRON SOURCE TERMS FOR FFTF SPENT FUEL

D-1 
TABLE D. 1

GAMMA SOURCE TERMS FOR FFTF FUEL ASSEMBLY

AFTER 150,000 MWd/MTHM BURNUP - 918 EFPD

\begin{tabular}{|c|c|c|c|c|c|}
\hline & $\begin{array}{l}\text { Meup } \\
\text { Energy }\end{array}$ & \multicolumn{4}{|c|}{ Source Terms (photons/s-assembly) } \\
\hline No. & $(\mathrm{MeV})$ & Year Decay & 2 Years Decay & 5 Years Decay & 10 Years Decay \\
\hline $\begin{array}{l}1 \\
2 \\
3 \\
4\end{array}$ & $\begin{array}{l}0.150 \\
0.250 \\
0.350 \\
0.475\end{array}$ & $\begin{array}{l}2.212+14 \\
1.339+13 \\
4.766+11 \\
5.443+14\end{array}$ & $\begin{array}{l}1.083+14 \\
5.927+12 \\
3.861+11 \\
2.766+14\end{array}$ & $\begin{array}{l}2.734+13 \\
1.399+12 \\
2.298+11 \\
4.531+13\end{array}$ & $\begin{array}{l}1.108+13 \\
7.353+11 \\
1.166+11 \\
4.888+12\end{array}$ \\
\hline $\begin{array}{l}5 \\
6 \\
7 \\
8\end{array}$ & $\begin{array}{l}0.650 \\
0.825 \\
1.000 \\
1.225\end{array}$ & $\begin{array}{l}1.206+15 \\
6.501+14 \\
5.429+13 \\
1.657+13\end{array}$ & $\begin{array}{l}8.867+14 \\
2.367+14 \\
3.033+13 \\
1.284+13\end{array}$ & $\begin{array}{l}5.608+14 \\
8.421+13 \\
8.973+12 \\
7.618+12\end{array}$ & $\begin{array}{l}4.894+14 \\
1.701+13 \\
3.141+12 \\
4.278+12\end{array}$ \\
\hline $\begin{array}{r}9 \\
10 \\
11 \\
12\end{array}$ & $\begin{array}{l}1.475 \\
1.700 \\
1.900 \\
2.100\end{array}$ & $\begin{array}{l}1.972+13 \\
2.377+12 \\
1.829+08 \\
1.194+13\end{array}$ & $\begin{array}{l}1.173+13 \\
1.155+12 \\
3.340+06 \\
4.896+12\end{array}$ & $\begin{array}{l}3.375+12 \\
1.475+11 \\
6.507+05 \\
3.382+11\end{array}$ & $\begin{array}{l}7.902+11 \\
4.789+09 \\
6.507+05 \\
3.934+09\end{array}$ \\
\hline $\begin{array}{l}13 \\
14 \\
15 \\
16\end{array}$ & $\begin{array}{l}2.300 \\
2.500 \\
2.700 \\
3.000\end{array}$ & $\begin{array}{l}2.502+08 \\
9.495+05 \\
0.000 \\
2.460+04\end{array}$ & $\begin{array}{l}1.286+05 \\
2.494-03 \\
0.000 \\
6.462-05\end{array}$ & $\begin{array}{l}1.737-05 \\
0.000 \\
0.000 \\
0.000\end{array}$ & $\begin{array}{l}6.285-22 \\
0.000 \\
0.000 \\
0.000\end{array}$ \\
\hline $\begin{array}{l}\text { Dos } \\
\text { (mR }\end{array}$ & $\begin{array}{l}\text { Rate* } \\
\text { r) }\end{array}$ & $1.09 \times 10^{4}$ & $5.43 \times 10^{3}$ & $1.80 \times 10^{3}$ & $8.03 \times 10^{2}$ \\
\hline
\end{tabular}

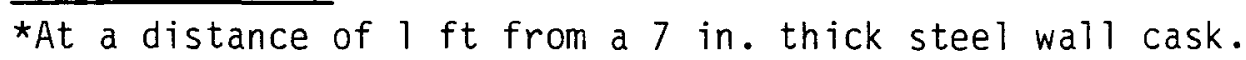


TABLE D.2

INNER DRIVER FFTF FUEL

\begin{tabular}{|c|c|c|c|c|c|c|c|c|}
\hline & Energy & & \multicolumn{6}{|c|}{ Neutron Source (n/s/Subassembly) } \\
\hline Group & Range & $\alpha$ * & O Years & 1 Year & 2 Years & 5 Years & 7.5 Years & 10 Years \\
\hline 1 & $\begin{array}{l}10 \mathrm{MeV} \\
3.7 \mathrm{MeV}\end{array}$ & 0.106561 & $7.58+6$ & $2.05+6$ & $8.61+5$ & $5.03+5$ & $4.65+5$ & $4.34+5$ \\
\hline 2 & $1.4 \mathrm{MeV}$ & 0.607230 & $4.32+7$ & $1.67+7$ & $4.90+6$ & $2.87+6$ & $2.65+6$ & $2.47+6$ \\
\hline 3 & $0.50 \mathrm{MeV}$ & 0.206418 & $1.47+7$ & $3.96+6$ & $1.67+6$ & $9.74+5$ & $9.01+5$ & $8.40+5$ \\
\hline 4 & $0.30 \mathrm{MeV}$ & 0.039251 & $2.79+6$ & $7.54+5$ & $3.17+5$ & $1.85+5$ & $1.71+5$ & $1.60+5$ \\
\hline 5 & $0.11 \mathrm{MeV}$ & 0.030741 & $2.19+6$ & $5.90+5$ & $2.48+5$ & $1.45+5$ & $1.34+5$ & $1.25+5$ \\
\hline 6 & $40.87 \mathrm{KeV}$ & 0.007524 & $5.35+5$ & $1.45+5$ & $6.08+4$ & $3.55+4$ & $3.28+4$ & $3.06+4$ \\
\hline 7 & $15.03 \mathrm{KeV}$ & 0.001691 & $1.20+5$ & $3.25+4$ & $1.37+4$ & $7.98+3$ & $7.38+3$ & $6.88+3$ \\
\hline 8 & $5.53 \mathrm{KeV}$ & 0.000402 & $2.86+4$ & $7.69+3$ & $3.25+3$ & $1.90+3$ & $1.75+3$ & $1.64+3$ \\
\hline 9 & $2.03 \mathrm{KeV}$ & 0.000092 & $6.55+3$ & $1.77+3$ & $7.43+2$ & $4.34+2$ & $4.02+2$ & $3.74+2$ \\
\hline 10 & $0.75 \mathrm{KeV}$ & 0.000022 & $1.57+3$ & $4.22+2$ & $1.78+2$ & $1.04+2$ & $9.60+1$ & $8.95+1$ \\
\hline 11 & $0.27 \mathrm{KeV}$ & 0.000005 & $3.56+2$ & $9.60+1$ & $4.04+1$ & $3.26+1$ & $2.18+1$ & $2.03+1$ \\
\hline 12 & $0.09 \mathrm{eV}$ & 0.000001 & $7.12+1$ & $1.92+1$ & 8.08 & 4.72 & 4.36 & 4.07 \\
\hline
\end{tabular}

$\star_{\alpha}=$ Source spectrum based on $60 \%$ spontaneous fission and $40 \%(\alpha, n)$ reactions (normalized to 1). 
TABLE D.3

INNER DRIVER FFTF FUEL

Isotopic Activities for Various Time Periods After Fuel Discharge

Curies/Subassembly

\begin{tabular}{|c|c|c|c|c|c|c|}
\hline \multirow[b]{2}{*}{ I sotope } & \multicolumn{6}{|c|}{ Curies/Subassembly } \\
\hline & 0 Years & 1 Year & 2 Years & 5 Years & 7.5 Years & 10 Years \\
\hline $240 \mathrm{pu}$ & $1.815+2$ & $1.815+2$ & $1.815+2$ & $1.814+2$ & $1.814+2$ & $1.813+2$ \\
\hline $241_{A m}$ & 91.10 & 90.96 & 90.81 & 90.38 & 90.01 & 89.65 \\
\hline${ }^{239} \mathrm{pu}$ & $2.672+2$ & $2.672+2$ & $2.672+2$ & $2.672+2$ & $2.672+2$ & $2.671+2$ \\
\hline $242 p u$ & $7.88-2$ & $7.88-2$ & $7.88-2$ & $7.88-2$ & $7.88-2$ & $7.88-2$ \\
\hline${ }^{242} \mathrm{~cm}$ & $9.185+3$ & $1.947+3$ & $4.125+2$ & 3.925 & $8.115-2$ & $1.678-3$ \\
\hline${ }^{244} \mathrm{Cm}$ & 30.18 & 29.05 & 27.96 & 24.94 & 22.67 & 20.61 \\
\hline \multirow[t]{3}{*}{${ }^{246} \mathrm{Cm}$} & $2.281-4$ & $2.281-4$ & $2.280-4$ & $2.279-4$ & $2.279-4$ & $2.278-4$ \\
\hline & \multicolumn{6}{|c|}{$n / s /$ Subassembly } \\
\hline & 0 Years & 1 Year & 2 Years & 5 Years & 7.5 Years & 10 Years \\
\hline $\begin{array}{l}\text { Neutron } \\
\text { Source }\end{array}$ & $7.12+7$ & $1.92+7$ & $8.08+6$ & $4.72+6$ & $4.37+6$ & $4.07+6$ \\
\hline
\end{tabular}

Shelf life, 8.5 years.

Nine cycles (102 EFPD), intervening outages of 48 days. 
TABLE $\quad 0.4$

FFTF FUEL ASSEMBLY, FISSION PRODUCT DECAY HEAT (KW)

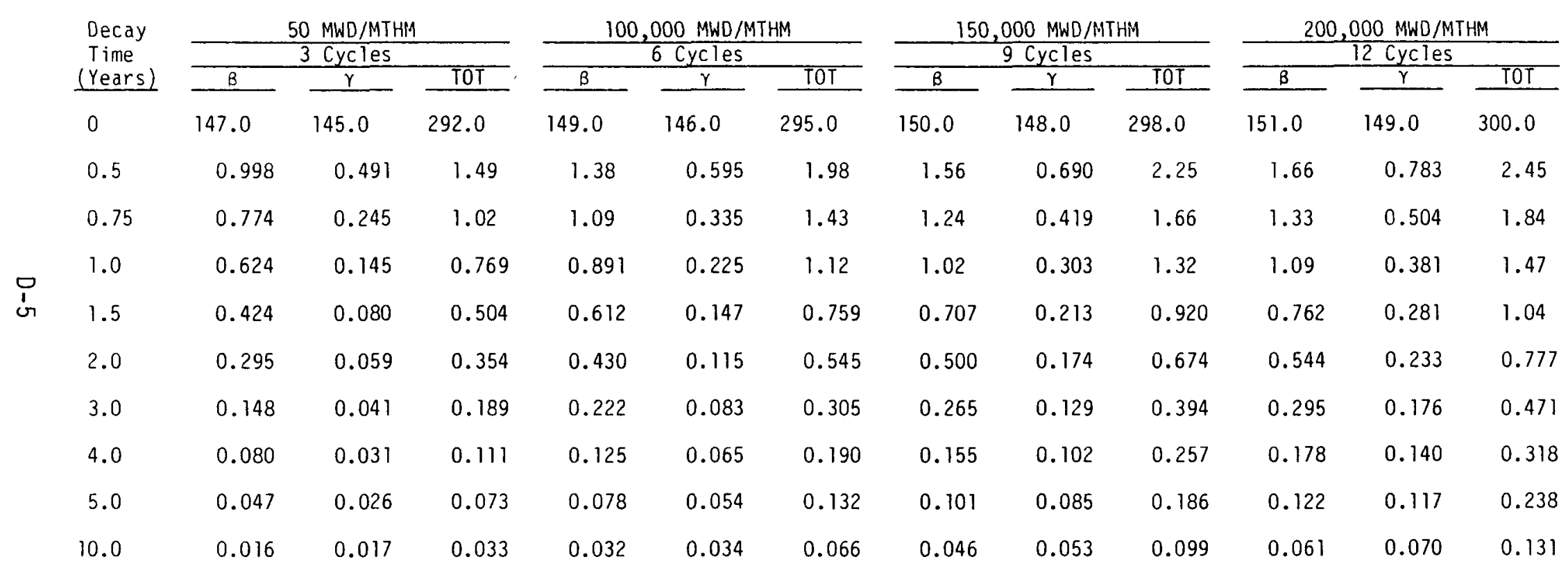

One Cycle

$5.5 \mathrm{MW}-100$ days

$0.0 \mathrm{MW}-40$ days 


$$
\text { A P PENDIX E }
$$

VITRIFIED WASTE LOG GAMMA RADIATION SOURCE TERMS

$$
\text { E-1 }
$$


TABLE E.1

VITRIFIED WASTE LOG GAMMA RADIATION SOURCE TERMS

(Based on Fuel Burnup of 150,000 MWd/MTHM)

Group

Mean

Energy

No. (MeV)

Source Terms (photons/s-metric tonne heavy metal)

10.150

1 Year

2 Years

7.5 Years

10 Years

0.150

$7.807+15$

$3.420+15$

$5.054+14$

$2.265+14$

$1.146+14$

$3 \quad 0.350$

$4.652+14$

$1.943+14$

$2.919+13$

$1.673+13$

$1.397+13$

$\begin{array}{ll}4 & 0.475 \\ 5 & 0.650\end{array}$

$.488+13$
$2.083+15$

$1.180+13$

$6.094+12$

$3.695+12$

$2.366+12$

$1.823+16$

$1.208+15$

$5.449+14$

$2.844+14$

$1.489+14$

0.825

$2.156+16$

$2.564+16$

$1.744+16$

$1.445+16$

$1.277+16$

$7 \quad 1.000$

$4.672+14$

$8.113+15$

$2.890+15$

$1.261+15$

$5.614+14$

$8 \quad 1.225$

$3.241+14$

$2.602+14$

$1.046+14$

$7.486+13$

$6.031+13$

$6.461+14$

$2.560+14$

$1.471+14$

$1.069+14$

$8.506+13$

$9 \quad 1.475$

$5.435+12$

$3.684+14$

$1.014+14$

$4.437+13$

$2.176+13$

$1.127+10$

$8.225+10$

0.000

0.000

0.000

$11 \quad 1.900$

$4.644+14$

$1.705+08$

0.000

0.000

0.000

$13 \quad 2.300$

$8.943+10$

$1.901+14$

$1.310+13$

$1.413+12$

$1.521+11$

$5.323+07$

0.000

0.000

0.000

Decay

Heat (kW)

32.0

12.0

3.8

3.1

2.8

Dose Rate*

(mR/hr)

$2.13 \times 10^{5} 1.10 \times 10^{5}$

$3.80 \times 10^{4}$

$2.36 \times 10^{4}$

$1.76 \times 10^{4}$

*This is the dose rate at $1 \mathrm{ft}$ from the surface of a 7 in. steel shield surrounding the vitrified HLLW $10 \mathrm{~g}$. 
CHARACTERISTICS OF BRET HLLW FEED TO VITRIFICATION SYSTEM

FROM REPROCESSING ON MTIHM Of FFTF FUEL $(\mathrm{a}, \mathrm{b}, \mathrm{c})$

\begin{tabular}{|c|c|c|c|c|c|}
\hline \multirow[b]{2}{*}{ Constituent } & \multirow{2}{*}{$\begin{array}{l}\text { Mass } \\
(\mathrm{g})\end{array}$} & \multicolumn{2}{|c|}{ Activity $(\mathrm{Ci})$ at } & \multirow{2}{*}{$\begin{array}{l}\text { Thermal } \\
180 \mathrm{~d}(\mathrm{~d}) \\
\end{array}$} & \multirow{2}{*}{$\begin{array}{l}\text { Power }(W) \text { at } \\
1 \text { year }(d)\end{array}$} \\
\hline & & $180 \mathrm{~d}(\mathrm{~d})$ & 1 year $(d)$ & & \\
\hline $\mathrm{Na}$ & 3.1 E 3 & & & & \\
\hline Gd & $2.6 \bar{E} 4$ & & & & \\
\hline TBP & $2.3 E 2$ & & & & \\
\hline $\mathrm{Na} \mathrm{DBP}$ & $5.1 E 2$ & & & & \\
\hline $\mathrm{Cr}$ & $1.5 E 3$ & $1.7 \mathrm{E} 0$ & $1.7 E-2$ & $3.7 E-4$ & $3.7 E-6$ \\
\hline $\mathrm{Fe}$ & 5.7 E 3 & $2.5 \mathrm{E} I$ & $2.1 \mathrm{E} 1$ & $4.1 E-3$ & $9.1 E-4$ \\
\hline $\mathrm{Ni}$ & 1.7 E 3 & $1.3 E 0$ & $1.3 \bar{E} 0$ & $5.1 E-4$ & $5.1 E-4$ \\
\hline $\mathrm{Se}$ & $6.5 \mathrm{E}]$ & $6.2 E-1$ & $6.2 E-1$ & $1.6 E-4$ & $1.6 E-4$ \\
\hline $\mathrm{Rb}$ & $3.7 \mathrm{E} 2$ & $1.7 \mathrm{E} \mathrm{T}$ & $1.8 E-2$ & $7.9 E-2$ & $8.1 E-5$ \\
\hline Sr & $8.3 E 2$ & $2.4 E 5$ & $8.0 \mathrm{E} 4$ & $6.8 \mathrm{E} 2$ & $1.2 \mathrm{E} 2$ \\
\hline$Y$ & $4.4 E 2$ & $3.9 E 5$ & $1.0 \mathrm{E} 5$ & 1.5 E 3 & $5.0 \mathrm{E} 2$ \\
\hline $\mathrm{Zr}$ & $4.5 E 3$ & $7.1 E 5$ & $1.0 \mathrm{E} 4$ & 3.6 E 3 & $4.8 \mathrm{E} 2$ \\
\hline $\mathrm{Nb}$ & $5.3 E 0$ & $1.4 E 6$ & $2.1 E 5$ & $6.7 \mathrm{E} 3$ & $1.0 \mathrm{E} 2$ \\
\hline Mo & $3.9 \mathrm{E} 3$ & $\sim 0$ & 20 & $\sim 0$ & $\sim 0$ \\
\hline Tc & 1.0 E 3 & $1.7 \mathrm{E} 1$ & $1.7 E-1$ & $8.7 E-3$ & $8.7 E-3$ \\
\hline Ru & $3.2 E 3$ & $1.2 E 6$ & 7.4 E 5 & $6.5 \mathrm{E}_{2}$ & $6.6 \mathrm{E}$ \\
\hline $\mathrm{Rh}$ & 8.6 E 2 & $1.1 E 6$ & 6.7 E 5 & 9.1 E 5 & $6.4 E 3$ \\
\hline $\mathrm{Pd}$ & $2.8 E 3$ & $3.2 E-1$ & $3.2 \mathrm{E}-1$ & $1.9 E-5$ & $1.9 E-5$ \\
\hline $\mathrm{Ag}$ & $2.6 E 2$ & $3.3 \mathrm{E} 3$ & $1.9 \mathrm{E} 3$ & $5.4 \mathrm{E}]$ & $3.2 \mathrm{E} I$ \\
\hline $\mathrm{Cd}$ & $2.9 E 2$ & $8.5 E 2$ & $2.0 \mathrm{E} 2$ & $2.8 \mathrm{E} 0$ & $4.2 \mathrm{E}-1$ \\
\hline Sn & $2.8 E 2$ & $8.8 E 3$ & $3.4 \mathrm{E} 3$ & $2.6 E 1$ & $9.7 \mathrm{E} 0$ \\
\hline Sb & $1.1 E 2$ & $5.3 E 4$ & $4.6 \mathrm{E} 4$ & $1.7 \mathrm{E} 2$ & $1.5 E 2$ \\
\hline $\mathrm{Te}$ & $9.9 E 2$ & $6.5 E 4$ & $2.4 \mathrm{E} 4$ & $7.3 E 1$ & $2.2 \mathrm{E} I$ \\
\hline I & $6.4 E-1$ & $9.5 E-4$ & $8.2 E-5$ & $3.0 E-6$ & $3.8 E-8$ \\
\hline Cs & $6.9 \mathrm{E} 3$ & $2.4 E 5$ & $2.3 E 5$ & 8.2 E 2 & $7.2 E_{2}$ \\
\hline $\mathrm{Ba}$ & $2.3 E 3$ & $1.7 E 5$ & 1.7 E 5 & $6.9 \mathrm{E} 2$ & $6.8 \mathrm{E} 2$ \\
\hline La-Dy & 1.6 E 4 & $4.0 E 6$ & 2.6 E 6 & 1.4 E 4 & 8.6 E 3 \\
\hline U & 3.5 E 3 & $3.9 E-2$ & $3.8 E-2$ & $1.1 E-4$ & $1.1 E-4$ \\
\hline $\mathrm{Np}$ & $2.6 \mathrm{E} 2$ & $8.3 E 0$ & $8.3 E 0$ & $3.2 \bar{E}-2$ & $3.2 \bar{E}-2$ \\
\hline $\mathrm{Pu}$ & 1.2 E 3 & 1.7 E 3 & $1.6 \mathrm{E} 3$ & $4.0 E 0$ & $4.1 E 0$ \\
\hline $\mathrm{Am}$ & $2.1 \mathrm{E} 3$ & 7.9 E 3 & 8.2 E 3 & 2.3 E 2 & $2.3 \mathrm{E} 2$ \\
\hline $\mathrm{Cm}$ & $2.6 \mathrm{E} 1$ & $1.7 E 5$ & $7.6 \mathrm{E} 4$ & 6.1 E 3 & $2.8 \mathrm{E} 3$ \\
\hline Total met & $\overline{9.1 E 4}$ & $\overline{9.7 E 6}$ & $\overline{5.0 E 6}$ & $\overline{4.4 E 4}$ & $2.2 E 4$ \\
\hline
\end{tabular}

$\mathrm{HNO}_{3}: 2 \mathrm{M}$

Volume: $\overline{6} 67$ 느 (176 gal) Density: $21.3 \mathrm{~g} / \mathrm{ml}$

(a) Based on FFTF fuel irradiated to 60,000 MWd/MTIHM at 150 MW/MTIHM.

(b) HLLW is a blend of HAW, solvent wash waste, and LLW concentrator bottoms.

(c) The following percentages of spent fuel constituents are present in the HLLW: $1 \%$ of the clad and hardware fed to dissolver, $72 \%$ Mo, $71 \%$ TC, $57 \%$ $\mathrm{Ru}, 52 \% \mathrm{Rh}, 80 \% \mathrm{Pd}, 62 \% \mathrm{Ag}, 93 \% \mathrm{Te}, 0.1 \%$ halogens, $0 \%$ noble gases, $99.95 \%$ other f.p.'s, $0.5 \% \mathrm{U}$ and Pu, 99.75\% Np, 99.95\% Am and $\mathrm{Cm}$.

(d) Time of fuel reprocessing. 
TABLE E.3

ISOTOPIC ACTIVITIES IN HLLW OPERATED TO 150,000 MWd/MTHM

\begin{tabular}{|c|c|c|c|c|c|c|}
\hline \multirow[b]{2}{*}{ I sotope } & \multirow{2}{*}{$\begin{array}{c}\text { Half-Life } \\
\text { T1/2 } \\
\end{array}$} & \multicolumn{5}{|c|}{ Activity (curies) } \\
\hline & & 1 Year & 2 Years & 5 Years & 7.5 Years & 10 Years \\
\hline${ }^{91} Y$ & $58.8 \mathrm{~d}$ & $3.80+4$ & 513.0 & $1.26-3$ & -- & -- \\
\hline${ }^{95} \mathrm{Zr}$ & $65.5 \mathrm{~d}$ & $1.12+5$ & 2350.0 & $2.16-2$ & -- & -- \\
\hline${ }^{95} \mathrm{Nb} \star$ & $90 \mathrm{hr}$ & 1460.0 & 47.0 & $4.40-4$ & -- & -- \\
\hline${ }^{95} \mathrm{Nb}$ & $35 \mathrm{~d}$ & $2.44+5$ & 2780.0 & $2.48-2$ & -- & -- \\
\hline${ }^{103} \mathrm{Ru}$ & $39.5 \mathrm{~d}$ & $1.47+4$ & 24.2 & -- & -- & -- \\
\hline${ }^{110} \mathrm{Ag}$ * & $255 d$ & 7030.0 & 2600.0 & 133.0 & 11.1 & 0.925 \\
\hline $110_{\mathrm{Ag}}$ & $25 \mathrm{~s}$ & 7030.0 & 2600.0 & 133.0 & 11.1 & 0.925 \\
\hline${ }^{113} \mathrm{Cd} *$ & $13.6 \mathrm{yr}$ & 885.0 & 841.0 & 722.0 & 635.0 & 559.0 \\
\hline${ }^{119} \mathrm{Sn}$ * & $250 d$ & 448.0 & 163.0 & 7.8 & 0.62 & 0.05 \\
\hline${ }^{123} \mathrm{Sn}$ & $125 d$ & 4430.0 & 585.0 & 1.34 & $8.50-3$ & -- \\
\hline${ }^{123} \mathrm{Te}$ * & $117 \mathrm{~d}$ & 31.7 & 3.64 & $5.50-3$ & -- & -- \\
\hline${ }^{124} \mathrm{Sb}$ & $60.4 \mathrm{~d}$ & 302.0 & 4.57 & -- & -- & -- \\
\hline${ }^{125} \mathrm{Sb}$ & $2.71 \mathrm{yr}$ & $9.74+4$ & $7.54+4$ & $3.50+4$ & $1.85+4$ & 9750.0 \\
\hline${ }^{125}{ }^{12}$ * & $58 d$ & $1.51+4$ & 4810.0 & 2180.0 & 1150.0 & 606.0 \\
\hline${ }^{127} \mathrm{Te} *$ & $109 d$ & 9980.0 & 978.0 & 0.921 & $2.80-3$ & -- \\
\hline${ }^{127} \mathrm{Te}$ & $9.4 \mathrm{hr}$ & 9780.0 & 978.0 & 0.921 & $2.80-3$ & -- \\
\hline${ }^{129} \mathrm{Te}^{*}$ & $34.1 \mathrm{~d}$ & 2520.0 & 1.5 & -- & -- & -- \\
\hline${ }^{129} \mathrm{Te}$ & $68.7 \mathrm{~min}$ & 2520.0 & 1.5 & -- & -- & -- \\
\hline${ }^{134} \mathrm{Cs}$ & $2.1 \mathrm{yr}$ & $3.27+5$ & $2.33+5$ & $8.46+4$ & $3.63+4$ & $1.56+4$ \\
\hline${ }^{137} \mathrm{Cs}$ & $30 \mathrm{yr}$ & $4.33+5$ & $4.23+5$ & $3.95+5$ & $3.73+5$ & $3.52+5$ \\
\hline${ }^{137} \mathrm{Ba}^{*}$ & $2.6 \min$ & $4.33+5$ & $4.23+5$ & $3.95+5$ & $3.73+5$ & $3.52+5$ \\
\hline & $32.5 \mathrm{~d}$ & 2320.0 & 0.96 & -- & -- & -- \\
\hline${ }^{144} \mathrm{Ce}$ & $284 d$ & $1.72+6$ & $7.05+5$ & $4.86+4$ & 5240.0 & 564.0 \\
\hline${ }^{144} \mathrm{Pr}$ & $17.3 \mathrm{~min}$ & $1.72+6$ & $7.05+5$ & $4.86+4$ & 5240.0 & 564.0 \\
\hline${ }^{148} \mathrm{Pm}^{\star}$ & $41.8 \mathrm{~d}$ & 555.0 & 1.3 & -- & -- & -- \\
\hline $148 \mathrm{Pm}$ & $5.4 \mathrm{~d}$ & 38.3 & -- & -- & -- & -- \\
\hline${ }^{152} E U$ & $12.7 \mathrm{yr}$ & 114.0 & 108.0 & 91.6 & 80.0 & 69.8 \\
\hline${ }^{154} \mathrm{EU}$ & $16 y r$ & 7720.0 & 7390.0 & 6490.0 & 5830.0 & 5230.0 \\
\hline${ }^{155} \mathrm{Eu}$ & $1.81 \mathrm{yr}$ & $1.83+4$ & $1.25+4$ & 3960.0 & 1520.0 & 583.0 \\
\hline $241_{A m}$ & $458 \mathrm{yr}$ & 5930.0 & 5920.0 & 5890.0 & 5870.0 & 5850.0 \\
\hline${ }^{242} \mathrm{~cm}$ & $163 d$ & $3.56+5$ & $7.50+4$ & 700.0 & 14.2 & 0.29 \\
\hline
\end{tabular}

$\overline{\text { *Represents }}$ parent - daughter relationships (e.g., ${ }^{137} \mathrm{Cs},{ }^{137_{B a}}$ ). 
A P P N D I X F

TRUNNION SKETCH

$F-1$ 

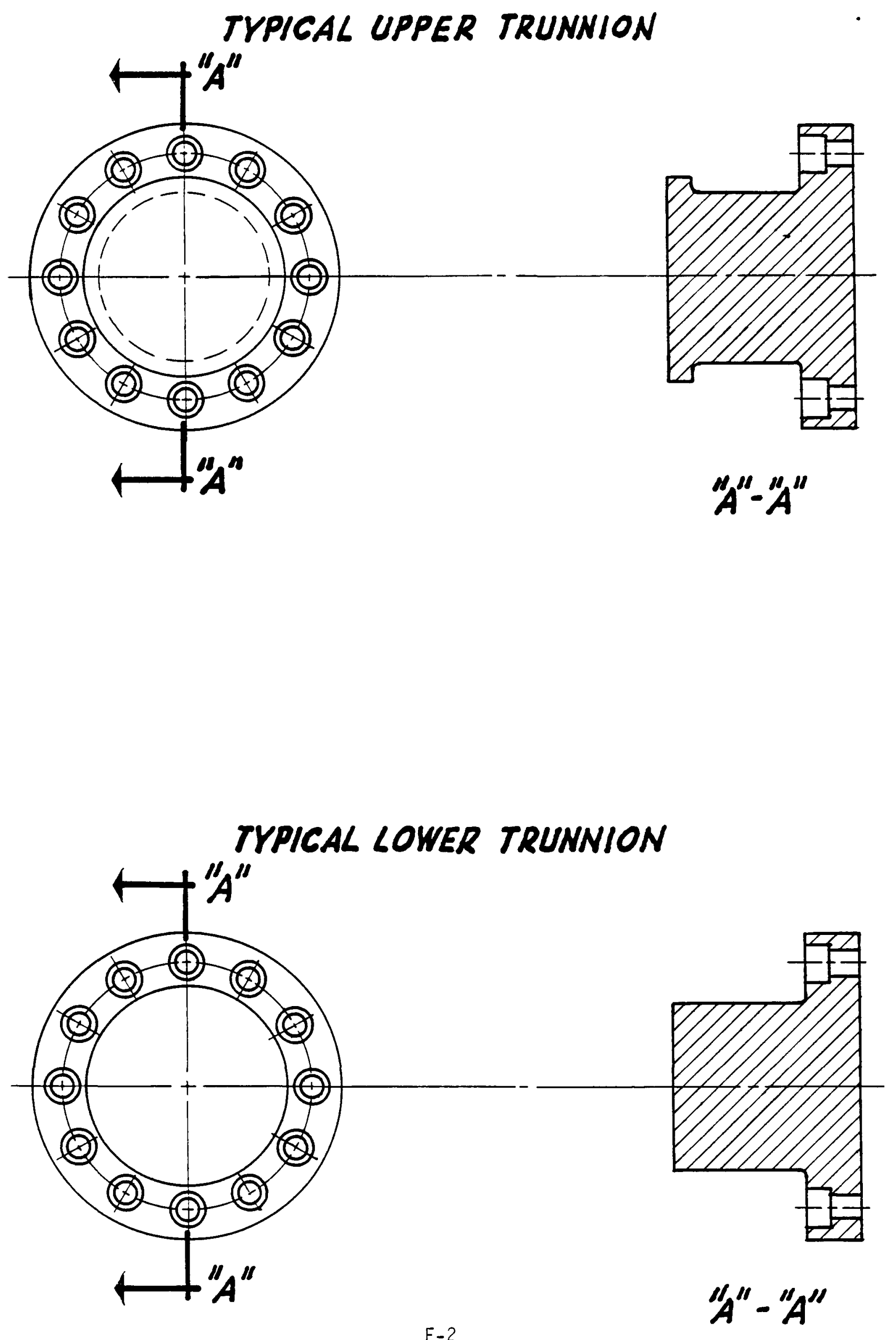


\section{DISTRIBUTION}

US Department of Eneroy Washington, DC 20545

$\begin{array}{lll}\text { RB Chitwood } & N E-42 & (2) \\ \text { DL Hoof } & N E-42 & (2) \\ \text { HF Walters } & N E-25\end{array}$

US Department of Energy Albuquerque Operations Office P. 0. Box 5400

(2)

A1buquerque, NM 87115

KG Golliher (2)

US Department of Energy

Chicago Operations Office 9800 South Cass Avenue

Argonne, IL 60439

WJ Griffing
US Department of Energy

Bichland Operations Office

RA Almquist

EC Norman

JR Patterson

(3)

Consolidated Management Office for the LMFBB One Energy Center Naperville, IL 68566

JM Yedidia

Sandia National Laboratories Iransportation Technology Center P. 0. Box 5800

Albuquerque, NM 87185

KB Sorenson Div. 6322 (10)

WE Wowak Div. 6322

HEDL

(39)

SO Arneson
JM Atwood
JD Berger
WF Brehm
WL Bunch
CA Burgess
CM Cox
AJ Duckett (20)
T. Hikido

$W / F-14$

$W / C-45$

$W / C-86$

$W / C-53$

$W / D-1$

$W / A-125$

$W / C-90$

W/C-86

W/A/72 